\title{
Territory impact on the performance of Spanish vacation hotels
}

\author{
Bartolomé Marco-lajara, Mercedes Úbeda-García, Vicente \\ SABATER-SEMPERE AND FRANCISCO GARCÍA-LILLO
}

Department of Business Organization, University of Alicante, Campus de San Vicente del Raspeig,E-03080 Alicante,Spain.E-mail: bartolome.marco@ua.es; mercedess.ubeda@ua.es; vicente.sabater@ua.es; f.garcia@ua.es. (Corresponding author: Bartolomé Marco-Lajara.)

\begin{abstract}
Although Spain is among the world's most visited tourist destinations, not all Spanish regions receive the same flow or number of tourists, and the type of visitor varies from one region to another. This paper analyses the structure of the tourism industry across the six most important tourist regions in Spain. Its main aim is to identify the most relevant factors for each of these regions, explaining the differences between them not only in terms of the number of tourists they receive but also in terms of tourist behaviour. The authors select two theoretical models empirically validated in previous studies: Porter's Diamond model, which helps to explain why the tourism industry is more competitive in some Spanish regions than in others, and the theory of tourist districts, which clarifies why the tourism industry tends to develop in very specific geographical areas.
\end{abstract}

Keywords: Diamond model; tourist districts; hotel performance; territory impact; vacation hotels; Spain

Our main objective in this study is to improve knowledge of the Spanish tourism sector. We focus on the reasons why hotels located in a given tourist destination are more profitable and competitive than those located in other destinations in the same country.

According to the strategic thinking approach, the performance and competitiveness of a firm may be explained through both external factors (the general socio-economic context of the geographical area where the firm is located and the structural characteristics of the industrial sector to which it belongs) and internal factors (the firm's own resources and capabilities). Our research refers exclusively to external factors and has as its theoretical framework Porter's (1990) Diamond model and the theory of tourist districts.

Hotel performance is measured through variables such as RevPar, ADR, occupancy and average length of stay of tourists. All this information can be 
easily obtained from the official statistics released by the Spanish government on a monthly basis, which provide the average value corresponding to each variable for the hotels located in each destination.

Furthermore, it must be remembered that the tourism statistics published in Spain can refer to four different geographical levels (autonomous regions, provinces, tourist areas and resort towns) although, in fact, the information is not always available for all four levels. In our case, the tourist destinations under analysis are the autonomous regions along with the resort towns located in each of them. However, the need to work with comparable destinations led us to study only those mainly and directly related to sun-and-sand tourism; in other words, destinations located along the whole of the Mediterranean peninsular coast, the Balearic Islands and the Canary Islands.

The remaining sections of this paper are structured as follows. After an initial review of the literature, the study develops into two distinct parts. First, an attempt is made using Porter's Diamond model to ascertain those external factors inherent to each destination or autonomous region that best explain the differences in the performance and competitiveness levels of their hotels. Second, the theory of tourist districts is applied in an effort to prove that the performance of hotels situated on the Spanish Mediterranean or along island coasts depends to a certain extent on whether or not the tourist destination or resort town where they are located can be considered a tourist district.

\section{Literature review}

This paper is based at least on two lines of research applied to the tourism industry: tourist destination competitiveness and tourist districts.

Regarding tourist destination competitiveness, most studies start from a territorial approach. In other words, they try to analyse the competitiveness of a destination or a territory as a whole, and not the competitiveness of the firms located there. Within this framework, some studies that formulate theoretical models list the factors affecting the competitiveness of a destination in a more or less exhaustive and orderly way. Among the most widely known contributions in this respect those by Crouch and Ritchie (1999) and Dwyer and Kim (2003) stand out. The application of these previously existing theoretical models in a number of empirical studies has also made it possible to rank a number of tourist countries or destinations on the basis of several indicators related to their attractiveness and competitiveness (Kozak and Rimmington, 1999; Hudson et al, 2004; Enright and Newton, 2005; Gooroochurn and Sugiyarto, 2005; Mazanec et al, 2007; Crouch, 2011; Mazanec and Ring, 2011). In Spain, we additionally have available the MONITUR report by Exceltur (2010), which ranks all Spanish autonomous regions according to their level of competitiveness.

Porter's (1990) Diamond model has been less frequently used to assess the competitiveness of tourist destinations. One of the studies applying this model was carried out by Perles et al (2011), who analysed the competitiveness of Spanish residential tourism destinations. Another study was published by Miller et al (2008). However, as we pointed out earlier, their application of the model seeks to assess the competitiveness of the territory as a whole, and not of the tourist firms located in a specific destination. 
According to the Diamond model, the conditions in each autonomous region that are likely to influence the competitive advantage of firms (hotels) located in it may be grouped into four categories: (i) factor conditions; (ii) demand conditions; (iii) related and complementary industries; and (iv) firm structure, strategy and rivalry. To these must be added two more factors that have an impact on all the other determinants: (v) government and (vi) chance. Any competitive advantage obtained arises not only from the influence exerted by one of these categories but also, and largely, from the continued interaction between all.

For the purposes of this study, the Diamond model will be the starting point from which to analyse how the socio-economic factors that define each Spanish autonomous region exert a particular influence on the competitiveness of the hotels situated in its territory. Nevertheless, the other contributions mentioned above will equally prove very helpful, since they create a suitable reference framework for ways in which the various factors or characteristics of each destination can be measured.

As for the theory of tourist districts, its origins can be traced back to the theory of industrial districts, first developed by Marshall (1890) and then recovered by Becattini (1979), who applied it to the Italian context. The main idea underlying this approach is that the small- and medium-sized (SME) firms located in an industrial district outperform those that are not. This would be because of the appearance of certain agglomeration economies or externalities linked to geographical concentration (the so-called 'district effect').

One of the most widely used definitions of an industrial district is that offered by Becattini $(1990,39)$, who refers to it as a socio-territorial entity characterized by the active presence of both a community of people and a group of firms in a naturally and historically delimited area'. Sengenberger and Pyke (1991) additionally point out that the most important components of a district are (i) the presence of highly dynamic SMEs belonging to the same industrial sector and geographically concentrated that have strong cooperation and competition links with one another, as well as high productive flexibility levels and relatively abundant specialized labour, and (ii) interpersonal relationships, social cohesion and interaction among firms, all of which favours an acceptable industrial climate, offering the trust and cooperation needed to ensure efficiency in the productive system.

On the basis of these concepts, any author trying to identify the existence of an industrial district in a given territory must set out to prove that there is a high geographical concentration of firms associated with the same industry, that those firms are SMEs and, finally, that a community of firms and people exists as well.

The assessment of SME firm concentration has mostly been carried out using agglomeration and/or specialization indicators, such as the Gini index, the Maurel-Sedillot index or the Herfindahl index (Ybarra, 1991). The most visible discrepancies emerge when it comes to selecting a territory as the starting point for a study. The problem lies in the fact that the local productive system must necessarily represent a community of firms and people. Some studies use administrative provinces as their base territory, but some of these may actually be too large for the notion of 'community'; others prefer local councils, but this criterion is also unsuitable at times, since some districts spread over different 
municipalities. Finally, some authors use local labour markets defined on the basis of residence-work mobility data, which in turn are obtained from population census statistics, as their territorial unit. The latter methodology has been amply developed by the Instituto Nazionale di Statistica (ISTAT, 1996, 1997) in Italy and later applied in Spain by Boix and Galletto (2005), who identified 806 local labour systems (LLS) throughout the Spanish territory.

The application of this theory to the tourism industry is quite recent and, therefore, research on tourist districts still finds itself in an early stage. Some of the most interesting contributions include the theoretical study by $\mathrm{Hjalager}$ (2000) and the empirical research carried out by Lazzereti and Capone (2008) for the Italian case. In Spain, some researchers have already started to deal with this topic: Álvarez and González (2006), Aurioles et al (2008) and Miret et al (2009), among others. Only the study by Lazzereti and Capone (2008) uses local labour markets as the territorial unit for the district, whereas the Spanish studies are based on provinces or, at best, on comarcas (small groupings of adjoining municipalities).

Our research is aimed at solving such a deficit through the implementation of the ISTAT methodology, for which the local labour systems identified by Boix and Galletto (2005) will be taken as a reference. The main task we have set ourselves is to apply certain concentration and/or specialization coefficients that can reveal which of these units actually represent a tourist district. A comparison may simultaneously be drawn between our results and those obtained for Italy.

\section{Spanish autonomous regions and the performance of sun-and-sand vacation hotels}

This paper applies the Diamond model to six Spanish regions (Figure 1), specifically the four regions located along the Mediterranean peninsular coastline (Catalonia, Valencian Region, Murcia and Andalusia) and the two island regions (Balearic and Canary Islands).

With this aim in mind, an assessment has been made of the diamond components through a number of indicators. Table 1 , which offers the numerical values for each one of the regions studied, also shows the value of four indicators used to assess the average performance of hotels in each region, from weaker to stronger performance. This makes it easier to observe which components in the diamond (that is, the factors inherent to each autonomous region) effectively help the hotels located in each destination to become more profitable and competitive. The information sources consulted for the calculation of values corresponding to these indicators were mainly official statistics.

We will now proceed to explain how each diamond component was assessed, simultaneously summarizing the main results collected in Table 1. Our analysis first concentrates on the performance of hotels in each region.

\section{Hotel performance}

Four main indicators - two of them financial and the other two strategic - have been used to measure hotel performance. The financial indicators are RevPar 


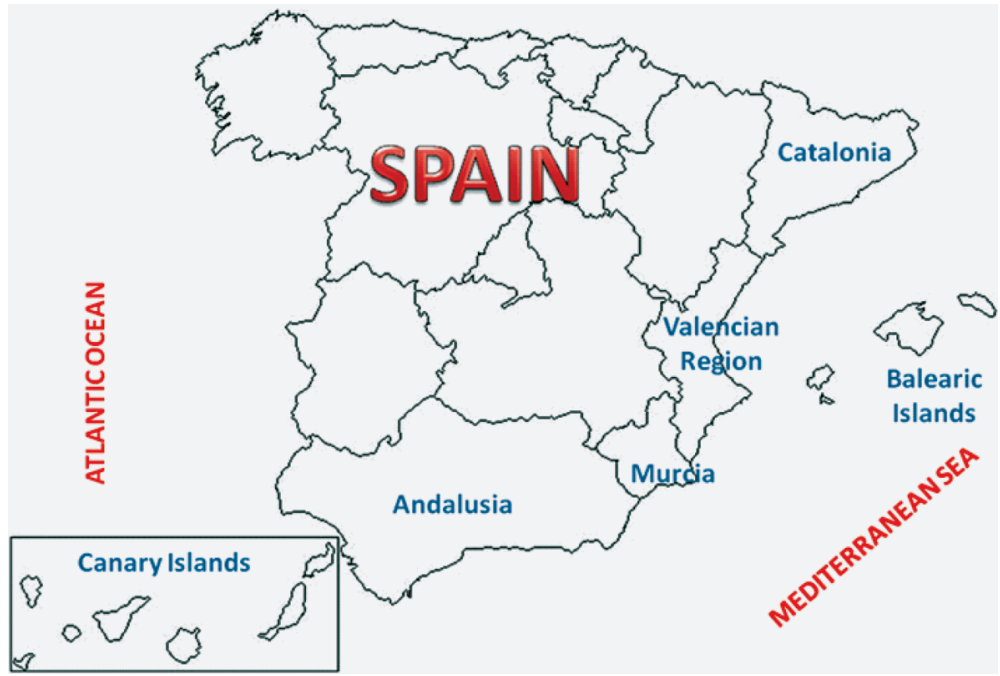

Figure 1. The main Spanish tourist regions.

and ADR, whereas the strategic ones are hotel occupancy and average stay. The results in Table 1 show that the most profitable hotels are located in the three regions of the Canary Islands, Balearic Islands and Catalonia, where at least three of the four profitability indicators examined reach higher values than in the other autonomous regions.

\section{Factor conditions}

A number of relativized indicators served to assess the factor conditions for each destination. At first, we paid attention only to the resources offered by the destination (those that, at the same time, provide the main reason for the trip) that may have an impact on hotel results. This is why products like linguistic, gastronomic or cruise tourism have not been considered; they do not usually generate hotel stays. Skiing resorts were also excluded because this product exerts only a limited influence in two of the regions studied. The star product of these destinations is sun and sea, but other resources equally have an important impact on the hotel industry, especially cultural heritage, conference venues, golf courses and marinas. With the exception of resources associated with cultural heritage, all the others have been studied through indicators that were relativized according to the number of potential users or the number of existing hotel beds. The number of potential users was calculated as follows:

$$
\text { Potential users }=\text { Inhabitants }+\frac{\begin{array}{c}
\text { Overnight stays } \\
\text { in hotels }
\end{array}}{365}+\frac{\begin{array}{l}
\text { Overnight stays } \\
\text { in apartments }
\end{array}}{365}
$$

As regards transport infrastructure, we were able only to consider the number of aircraft operations in each autonomous region (also relativized according to the number of potential users) and had to discard railways and road infrastructure. 
This is because tourists from other regions and other countries cannot use these types of transport to reach the regions that obtain the best results for their hotels (Canary Islands and Balearic Islands).

Finally, the knowledge resources taken into consideration refer to university education (measured through the number of university centres offering education in tourism, relativized according to the number of inhabitants in each specific region), to tourism research centres (number of existing public and/or private technological institutes, including university institutes that focus their activity on tourism research), and to the existence of an official tourism observatory that depends on the respective regional government (we have considered the years elapsed since its creation).

Of all these elements and indicators, those showing the highest values in some of the autonomous regions with the most profitable and competitive hotels (Canary Islands and Balearic Islands) are: linear metres of beach per potential user; number of golf holes per potential user; number of berths in marinas per potential user; number of aircraft operations; number of university centres offering education in tourism per inhabitant; and number of years since the official tourism observatory for the autonomous region opened its doors. Therefore, non-crowded beaches, air connectivity, resources related to high purchasing power or quality tourism (nautical and golf tourism), and knowledge resources (university resources and a powerful tourism observatory) appear as the most important destination resources regarding hotel competitiveness.

\section{Demand conditions}

The number of overnight stays in hotels (as a whole, only of residents in Spain and only of non-residents) relativized according to the number of hotel beds and the average daily expenditure of non-resident tourists were the indicators used to analyse hotel demand behaviour. The results in Table 1 are revealing: not surprisingly, the autonomous regions with a higher ratio of non-residents' overnight stays, and where these tourists have a higher daily expenditure, are also the destinations with the best hotel performance and competitiveness levels.

\section{Related and complementary industries}

Many complementary or ancillary services could be analysed (for example, the existence of shopping centres and, in general, of retail outlets), but there is one service that plays an essential role for tourists: restaurants. For this reason, we decided to place the emphasis on analysing the catering industry and studied the number of restaurants (as a whole, with Michelin stars and with forks ${ }^{1}$ ) relativized according to the number of potential users, which in this case was calculated using this formula:

$$
\text { Potential restaurant users }=\text { Inhabitants }+\frac{\begin{array}{c}
\text { Overnight stays } \\
\text { in hotels }
\end{array}}{365}+\frac{\begin{array}{l}
\text { Overnight stays } \\
\text { in apartments }
\end{array}}{365}
$$




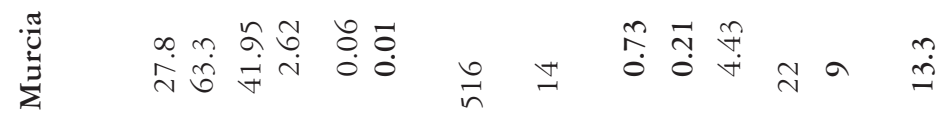

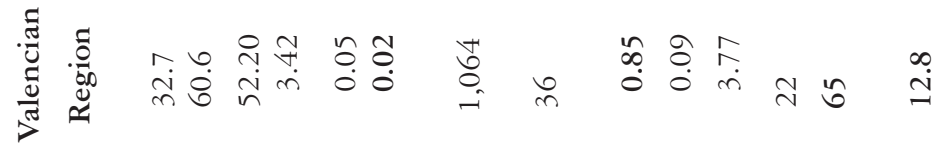

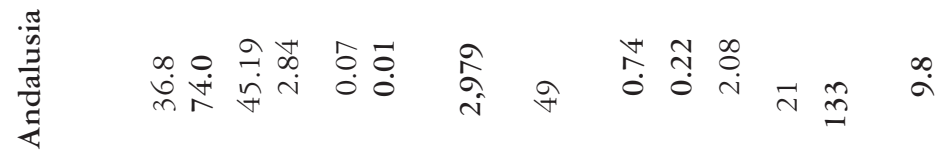

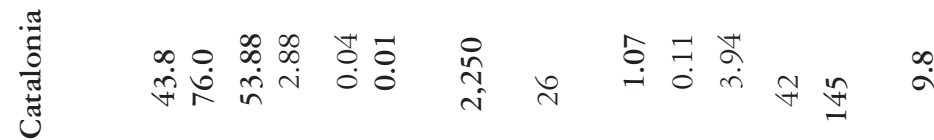

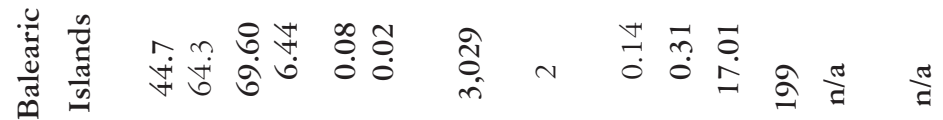

氙商
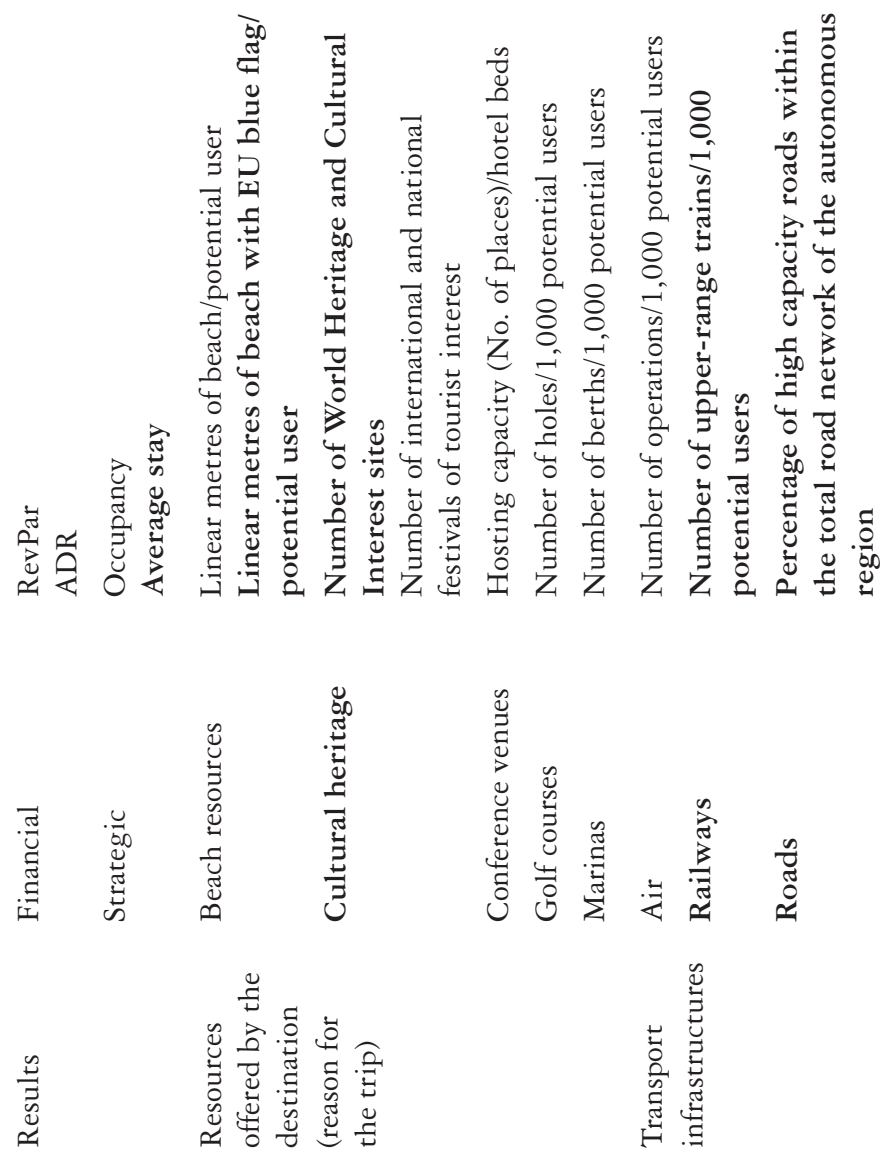

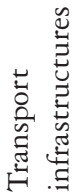




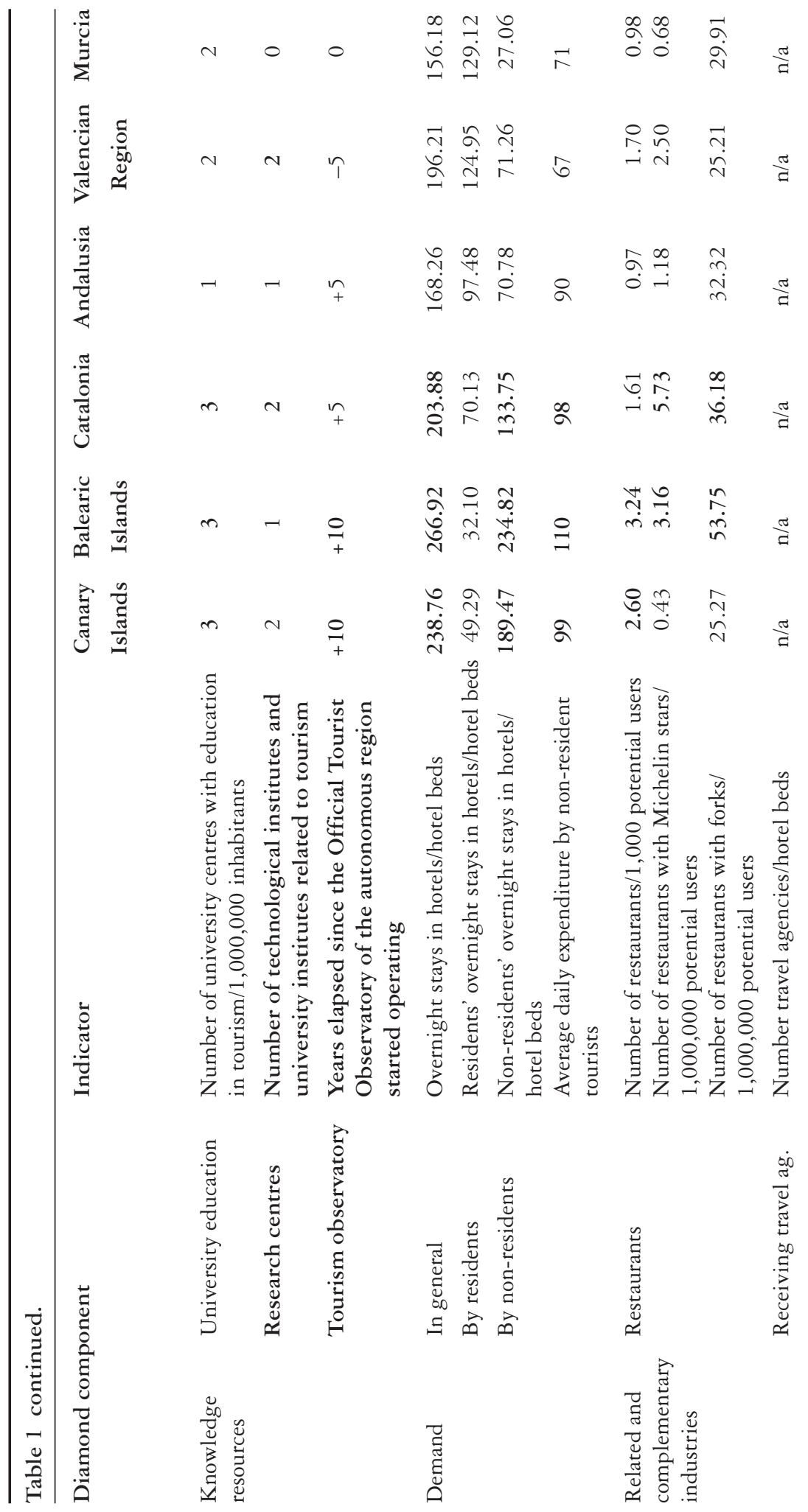




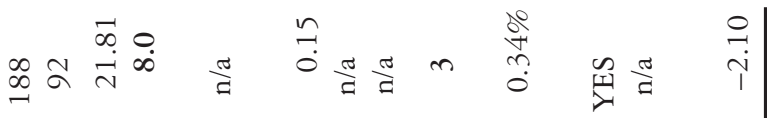

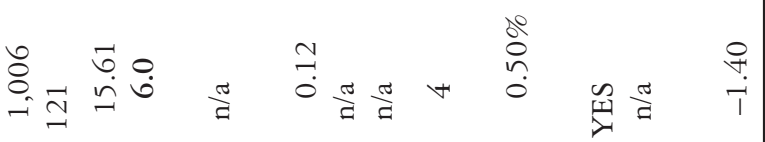

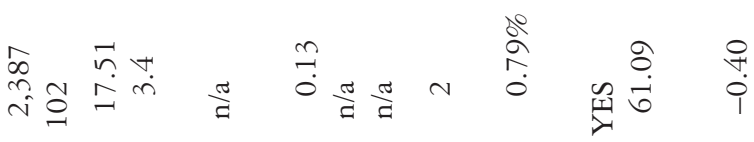

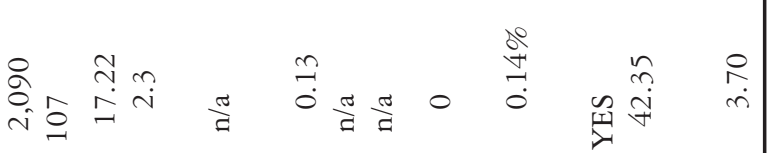

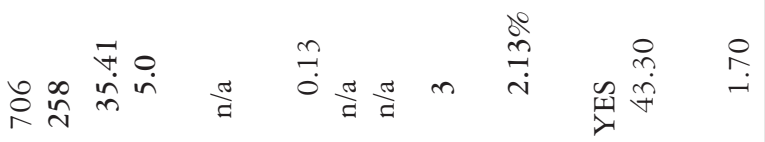

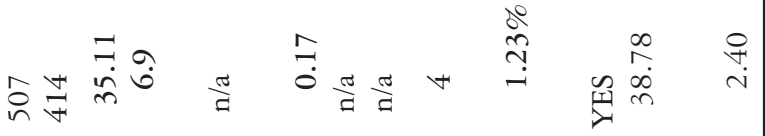

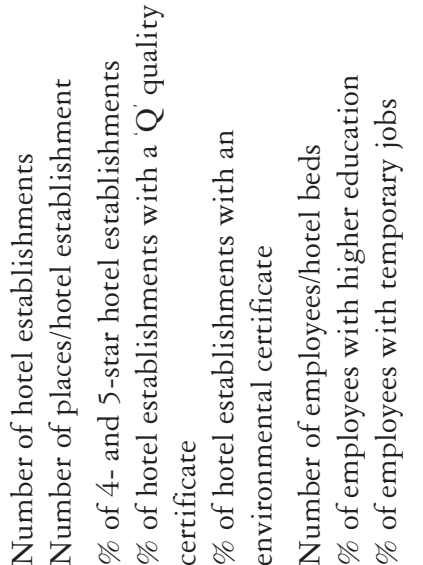

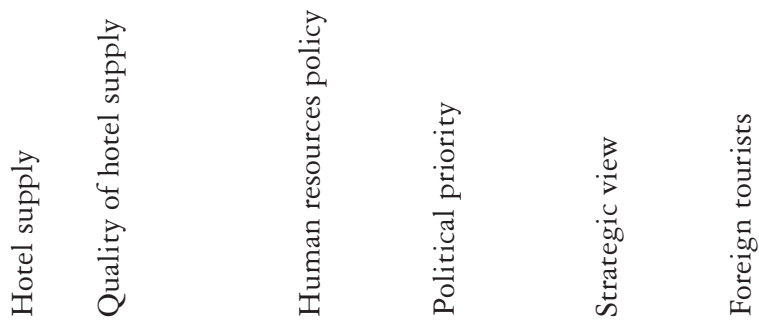

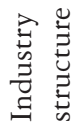


It can be clearly inferred from Table 1 that all three indicators have high values in at least one of the autonomous regions where hotels show higher performance rates. Therefore, the availability of a non-crowded restaurant service becomes as important as the availability of a high-quality restaurant service in this case.

\section{Firm structure, strategy and rivalry}

These aspects were covered using the number of hotel firms present in each region, along with their relative size (measured by means of the number of hotel beds in each accommodation establishment). Our study also considers the strategic orientation of hotels towards quality (3- and 4-star establishments, and establishments with the 'Q' quality certification) and their human resources policies. In the last case, only one of the three indicators proposed could finally be used: number of employees per hotel bed. Unfortunately, there is no information available on the percentage of employees in the hotel industry who have completed higher education studies and who have temporary jobs: the information offered by the official statistics only shows the aggregate results for the whole of the tourism industry.

The results obtained reveal that the number of firms alone is not sufficient to determine the competitiveness level, although company size is indeed a good indicator. In fact, precisely the two destinations with the most profitable establishments are also the ones with the greatest relative size of establishments. According to our interpretation, this happens because larger hotels tend to have more professionalized management teams, which in turn has an obvious impact upon business results. As for hotel quality, this factor is clearly essential if one considers the number of stars of each establishment, but quality certification is actually irrelevant and has no influence whatsoever upon business results. Finally, the number of employees available per establishment emerges as a relevant factor also.

\section{Government}

In our view, a number of factors are likely to exert an influence upon competitive advantage in the context of the tourism industry. More specifically, one might consider the political priority attached to the industry by the government of each autonomous region, together with the strategic view of tourism. These factors have been dealt with using several indicators: position of tourism within the regional government's organizational chart (the value is 4 when tourism has its own regional ministry or department; 3 when it shares a ministry with another area; 2 when it shares it with another two areas; 1 when it shares it with another three areas; and 0 when tourism does not appear at all as a ministry in the organizational chart); percentage of the total regional government budget allocated to the tourism department; availability of a strategic plan, and percentage of the tourism budget allocated to commercial promotion.

Of all these factors, only the tourism budget for each autonomous region seems to play a determining role for the performance of hotels located in each destination. 


\section{Chance}

Finally, unforeseen circumstances may have asymmetric effects on different nations and regions. For instance, the recent uprisings in Arab countries have placed Spain in an advantageous position as European tour operators prefer Spain to other rival Mediterranean destinations, which are potentially, or perceived to be, less safe at the moment.

It is difficult to estimate the extent to which chance can differently affect the competitiveness of each Spanish tourist destination, as they all form part of the same national, political and economic reality. Nevertheless, the growth of foreign tourist arrivals in each region can be a reliable indicator in our opinion. According to the results offered in Table 1, the autonomous regions with a higher ratio are also the destinations where hotels achieve the best performance and competitiveness levels.

\section{Spanish resort towns and the performance of sun and sand vacation hotels}

The Diamond model has helped us to detect some of the characteristic factors that are specific to each Spanish autonomous region and that initially seem to have an impact on the competitiveness level that hotels achieve in each of the six regions studied. However, hotels within the same region may show different performance rates, and an exploration below the regional analysis level is necessary to discover the reasons for this. We have consequently applied the tourist district model, according to which the hotels located inside a tourist district must necessarily achieve higher performance rates than those located beyond the boundaries of such a district.

The study started with the selection of the resort towns situated in the previously studied autonomous regions and for which official data on hotel average performance were available (ADR, RevPar and average occupancy). These data had been collected by the Spanish Statistics Institute (INE, in Spanish) and published by the Tourism Studies Institute (IET, in Spanish). A total of 53 tourist destinations or resort towns along the Mediterranean coast and in the Canary and the Balearic Islands were, as a result, included in our study.

The next stage involved checking which of these resort towns were actually districts and which ones were not. As shown in the theoretical review, we applied the ISTAT methodology with two main goals, namely: identifying the LLS that exist on the Spanish coast; and checking which of these LLS could actually be described as tourist districts - insofar as their SMEs had employment rates above the Spanish average.

Spanish LLS had already been identified by Boix and Galletto (2005), which is why we based our study on their findings. Our main task consisted in determining the LLS to which each one of the 53 previously selected resort towns belonged. This led us to identify 53 LLS too, as no two resort towns belonged to the same LLS.

The result of Equation (3) must be greater than 1 for the tourism industry employment rates of specific LLS to be above the national average: 


\section{$\mathrm{Z} \frac{\text { Tourism employment in destination } i}{\text { Total employment in destination } i} \div \frac{\text { Tourism employment in Spain }}{\text { Total employment in Spain }}>1$}

Furthermore, as the district mostly comprises SMEs, the result of the equation also needs to be greater than 1 when considering only enterprises with less than 250 employees.

The data used to estimate the equation corresponding to each LLS were obtained from the Spanish Chambers of Commerce enterprise database (Camerdata), updated in January 2011. The fact that this database does not include the exact number of employees hired by a company but rather the range within which a company lies in relation to this criterion forced us to use a middle ground for each range. We regard the tourism industry as consisting of hotels, restaurants and cafés (which together form the acronym HORECA); this approach can also be found in many other studies.

The results (Table 2) show that nearly all LLS are tourist districts, which is

Table 2. Sun-and-sand tourist destinations and districts in Spanish Mediterranean coast and in Balearic and Canary Islands.

\begin{tabular}{|c|c|c|c|}
\hline Region & Destination & LLS & $Z$-value \\
\hline Canary Islands & Yaiza & Yaiza & 4.89 \\
\hline Balearic Islands & Santa Margalida & Santa Margalida & 4.02 \\
\hline Valencian Region & Peñíscola & Peñíscola & 3.93 \\
\hline Canary Islands & Adeje & \multirow{2}{*}{ Adeje } & \multirow{2}{*}{3.88} \\
\hline Canary Islands & Arona & & \\
\hline Balearic Islands & Sant Llorenç des Cardassar & Sant Llorenç des Cardassar & 3.47 \\
\hline Canary Islands & Pájara & Pájara & 3.42 \\
\hline Balearic Islands & Capdepera & Capdepera & 3.18 \\
\hline Canary Islands & La Oliva & La Oliva & 3.11 \\
\hline Canary Islands & Teguize & Teguize & 3.06 \\
\hline Balearic Islands & Calviá & Calviá & 2.92 \\
\hline Balearic Islands & Alcudia & Alcudia & 2.87 \\
\hline Canary Islands & Mogán & \multirow{2}{*}{ San Bartolomé de Tirajana } & \multirow{2}{*}{2.79} \\
\hline Canary Islands & San Bartolomé de Tirajana & & \\
\hline Valencian Region & Benidorm & Benidorm & 2.72 \\
\hline Balearic Islands & Santanyi & Santanyi & 2.61 \\
\hline Andalusia & Benalmádena & Benalmádena & 2.45 \\
\hline Balearic Islands & Eivissa & \multirow{4}{*}{ Eivissa } & \multirow{4}{*}{2.29} \\
\hline Balearic Islands & Sant Antoni de Portmany & & \\
\hline Balearic Islands & Sant Josep de Sa Talaia & & \\
\hline Balearic Islands & Santa Eulalia des Rius & & \\
\hline Canary Islands & Tías & Tías & 2.28 \\
\hline Balearic Islands & Muro & Muro & 2.21 \\
\hline
\end{tabular}




\begin{tabular}{|c|c|c|c|}
\hline Catalonia & Roses & Roses & 2.16 \\
\hline Andalusia & Mójacar & Mójacar & 2.15 \\
\hline Catalonia & Lloret de Mar & Lloret de Mar & 1.99 \\
\hline Andalusia & Almuñécar & Almuñécar & 1.87 \\
\hline Andalusia & Fuengirola & Fuengirola & 1.85 \\
\hline Andalusia & Conil de la Frontera & Conil de la Frontera & 1.85 \\
\hline Andalusia & Isla Cristina & Isla Cristina & 1.85 \\
\hline Catalonia & Calella & \multirow{2}{*}{ Calella } & \multirow{2}{*}{1.79} \\
\hline Catalonia & Santa Susana & & \\
\hline Balearic Islands & Llucmajor & \multirow{2}{*}{ Palma } & \multirow{2}{*}{1.77} \\
\hline Balearic Islands & Palma & & \\
\hline Andalusia & Estepona & Estepona & 1.77 \\
\hline Balearic Islands & Ciutadella & Ciutadella & 1.74 \\
\hline Andalusia & Marbella & Marbella & 1.73 \\
\hline Andalusia & Puerto de Santa María & Puerto de Santa María & 1.53 \\
\hline Andalusia & Roquetas de Mar & Roquetas de Mar & 1.53 \\
\hline Andalusia & Chiclana de la Frontera & Chiclana de la Frontera & 1.51 \\
\hline Catalonia & Castell-Platja D’Aro & Castell-Platja D'Aro & 1.43 \\
\hline Valencian Region & Denia & Denia & 1.40 \\
\hline Balearic Islands & Manacor & Manacor & 1.39 \\
\hline Catalonia & Cambrils & \multirow{3}{*}{ Reus } & \multirow{3}{*}{1.34} \\
\hline Catalonia & Vila-Seca & & \\
\hline Catalonia & Salou & & \\
\hline Andalusia & Tarifa & San Roque & 1.31 \\
\hline Canary Islands & Puerto de la Cruz & Santa Cruz & 1.30 \\
\hline Valencian Region & Gandía & Gandía & 1.12 \\
\hline Murcia & Cartagena & Cartagena & 1.11 \\
\hline Andalusia & Torremolinos & Málaga & 0.97 \\
\hline Catalonia & Sitges & Barcelona & 0.88 \\
\hline Valencian Region & Benicásim & Castellón de la Plana & 0.82 \\
\hline
\end{tabular}

not surprising if we take into account that the object of the present study were the Spanish coastal towns with the highest concentration of hotels. Only three towns were not tourist districts because the presence of a large industrial city inside their LLS weakened the effects of tourism.

Such results make it impossible to verify the starting hypothesis for this study, that is, that hotels belonging to tourist districts outperform those which do not belong to them. Nevertheless, it is possible to analyse whether hotels in tourist destinations with a greater agglomeration effect have better performance rates than those located in districts with a lower agglomeration effect.

With this aim in mind, we divided the 53 previously selected resort towns (which actually constitute 53 tourists districts) into two groups, depending on whether the value of the equation measuring tourist concentration was above 
or below 2. As a result, the group with a greater agglomeration effect contained 25 destinations, while the remaining 28 destinations were included in the group with a lower agglomeration effect.

Average performance was calculated for each group (that is, average ADR, RevPar and occupancy) after which we carried out hypothesis testing for equal mean values in independent samples. The results not only confirm that differences between average hotel performance rates are statistically significant but also prove the hypothesis according to which the average performance (in terms of occupancy) of hotels located in a tourist district with an extremely high agglomeration effect is higher than that of hotels located in a district with the lowest agglomeration effect.

In any case, our study produced an unexpected finding: when average performance is estimated in terms of ADR and RevPar, the hotels located in a tourist district with a greater agglomeration effect turn out to be less profitable than those belonging to a district with a lower agglomeration effect. The only explanation that we can initially provide would have to do with the fact that the saturation of hotels in a particular destination is likely to impact negatively upon the potential profitability to be achieved by companies.

\section{Discussion and conclusion}

This study was conceived mainly as an attempt to identify the external or environmental factors that help sun-and-sand vacation hotels in Spain to become more competitive. These factors are usually associated with a specific geographical context; more precisely, the tourist destination where the hotels are located. That is why we decided to analyse the Spanish tourist destinations located on the Mediterranean peninsular coast and in the Canary and the Balearic Islands. The destinations examined in that part of the Spanish territory include, on the one hand, the six Spanish autonomous regions mentioned above and, on the other hand, the resort towns located in that part of Spain.

The analysis of the autonomous regions was carried out by applying Porter's Diamond model to each of the six regions. Our work involved assessing the Diamond model elements for each region through a number of relativized indicators, after which we identified the indicators that showed a significantly different value for those autonomous regions where hotels achieve profitability levels above the average. This made it possible to demonstrate how certain factors specific to the regions might lead to increased performance and competitiveness levels in their hotels.

Generally speaking, the factors that seem to influence hotel profitability to a greater extent are: knowledge resources, demand by non-residents, some factors related to industry structure (number of places per hotel establishment or establishment size, and percentage of 4- and 5-star hotel establishments), and the political priority attached to this industry by the government of each autonomous region, along with the strategic view of tourism. What surprises us, though, is the fact that some indicators usually associated with high-quality tourism (such as conference venues, golf courses and marinas) do not seem to play a determining role in the efforts to increase hotel profitability. Finally, it is worth highlighting that there are other indicators that should be associated with higher profitability levels, at least in theory; unfortunately the lack of 
information about them made it impossible to check their actual influence.

In any case, one of the main contributions of this paper lies in its attempt to identify the factors associated with each region that can explain the difference in profitability between the hotels in the six autonomous regions analysed. Studies published to date focus on the global effect that location can have on business performance. One example is that by Pereira et al (2011), who obtain precise empirical evidence showing that the autonomous region where the hotels are situated affects their profitability - which partially supports our conclusions. The problem about these studies is that they do not attempt to identify the specific territorial factors that explain the firm performances. This is therefore a task that will have to be validated in subsequent studies.

Nevertheless, it is also worth highlighting that hotel profitability depends not only on the resources available in its territory. In fact, many studies stress the importance of each firm's own resources (productive, human or technological ones, the brand, and so forth) as the main factor triggering profitability (Rumelt, 1991; Short et al, 2007), despite the influence that territory-related resources - especially those inherited - may exert on business performance (Cracolici et al, 2008; Gomezelj and Mihaliè, 2008). In any case, since it applies Porter's Diamond model, our study considers that the resources associated with the territory also include some related to the actual firms based in that territory, such as the establishment's size, category or quality level. In this respect, the highest percentage of 4- and 5-star hotels, large establishments and even those affiliated to major hotel chains are located in the Balearic and the Canary Islands; this is perhaps the reason for the higher profitability achieved by the establishments located there.

In the case of resort towns, the tourist district theory served as the basis for the analysis of 53 destinations. The results show that hotels located in towns with a greater agglomeration effect tend to be more profitable in terms of occupancy than those located in towns with lower agglomeration effects. However, when hotel performance is measured in terms of ADR and RevPar, the results are surprisingly just the opposite; hotels in destinations with a greater agglomeration effect tend to be less profitable. The results obtained are somehow logical, since the hotels located in one destination strongly compete with one another in their efforts to fill their own establishments (which results in an increased average occupancy for the destination), but they usually achieve their aim through a reduction of prices (which inevitably leads to lower income).

The results obtained from our research are not completely atypical, however. Thus, even if some studies dedicated to the hotel sector have found evidence that agglomeration heightens demand (Chung and Kalnins, 2001; Kalnins and Chung, 2004), others have concluded that firms located near one another achieve lower profits because proximity is associated with greater competition and decreasing marginal utility (Baum and Mezias, 1992; Baum and Haveman, 1997). One of the main contributions of our study is precisely that it supplies empirical evidence of both effects.

Therefore, the classic controversy about the effects of agglomeration on business performance still exists: although profitability can increase as a result of the externalities generated within an industrial or tourist district, it is not 
less true that the rivalry existing between nearby firms might reduce their profitability levels as well. This makes us wonder whether the theory of industrial districts can actually be applied to the tourism industry. In our opinion, it can be applied to tourism, but we still do not know exactly how. Taking as a reference the way we have applied this theory in the present paper, a possible enlargement of the study could involve estimating the degree of agglomeration up to which hotels would increase their profitability both in terms of occupancy and regarding income (ADR and RevPar). That degree of agglomeration would actually represent the turning point from which the profitability measured in terms of income would decrease even if the average occupancy continues to increase.

The practical implications of our study results are relevant both for public administrations and for hotel firms themselves. In effect, when firms have to decide where to locate, they must be aware that some autonomous regions are more attractive than others because of the resources associated with the territory. They should additionally take into account that it is not enough to find a location in a coastal municipality merely on the grounds that the tourist's main demand is for sun and beach, because a high saturation of firms may have counterproductive effects on hotel profitability. As shown in our study, the average occupancy may increase, but the profitability measured in terms of ADR and RevPar is likely to decrease. In other words, all the tourist locations analysed in this study belong to the Spanish coast and are considered tourist districts, but some underperform others.

With regard to the implications for public administrations, the governments of autonomous regions must invest in infrastructure and support the tourism industry with their policies if they want firms that can be profitable and competitive in the long term to settle in their territory. In turn, local governments should apply town-planning policies that favour the development of this industry but without reaching high saturation levels; in that case, low hotel performance may eventually lead to an unsustainable situation, especially when Spanish tourist destinations have to face the growing competition of other lowcost foreign substitutive destinations.

One of the most important limitations of this study stems from the fact that our analysis was based on secondary information sources that did not provide data on the GopPar (Gross Operating Profit Per Available Room), which is most probably a better indicator of hotel performance than those used here. A hotel's profitability is not only measured in terms of its revenues; its costs must also be considered. Thus, not only the revenues but also the costs of hotels located in a tourist district with a high degree of agglomeration might be low, which would imply a high profit margin. Nevertheless, it speaks in our favour that most of the studies on hotels use occupancy, ADR and RevPar as profitability measures, since these data are published in the official statistics. From this point of view, it is better to use these indicators, as it allows us to compare our results easily with those obtained in other studies.

\section{Endnote}

1. Instead of stars, the Spanish restaurant system uses forks to classify establishments. Restaurants are rated on a scale of one to five forks. Five forks is the highest. 


\section{References}

Álvarez, J.A., and González, O. (2006), 'Base de conocimientos y capacidad innovadora de los sistemas locales de producción turística española', paper presented at the XII Congreso Nacional de ACEDE, San Sebastián, Spain.

Aurioles, J., Fernández, M.C., and Manzanera, E. (2008), 'El distrito turístico', Mediterráneo, Vol 13, pp 299-326.

Baum, J.A.C., and Haveman, H.A. (1997), 'Love thy neighbor? Differentiation and agglomeration in the Manhattan hotel industry, 1898-1990', Administrative Science Quarterly, Vol 42, No 2, pp 304-338.

Baum, J.A.C., and Mezias, S.J. (1992), 'Localized competition and organizational failure in the Manhattan hotel industry, 1898-1990', Administrative Science Quarterly, Vol 37, No 4, pp 580_ 604.

Becattini, G. (1979), 'Dal settore industrial al distretto industrial. Alcune considerazioni sull'unità di indagine in economia industriale', Revista di Economía e Politica Industriale, Vol 1, pp 7-14.

Becattini, G. (1990), 'The marshallian industrial district as a socio-economic notion', in: Pyke, F., Becattini, G., and Sengenberger, W., eds, Industrial Districts and Inter-Firm Cooperation in Italy, International Institute for Labour Studies, Geneva, pp 37-51.

Boix, R., and Galletto, V. (2005), 'Sistemas locales de trabajo y distritos industriales marshallianos en España', Working Paper 05.14, Departament d'Economia Aplicada, Universitat Autònoma de Barcelona.

Chung, W., and Kalnins, A. (2001), 'Agglomeration effects and performance: a test of the Texas lodging industry', Strategic Management Journal, Vol 22, No 10, pp 969-988.

Cracolici, M.F., Nijkamp, P., and Rietveld, P. (2008), 'Assessment of tourism competitiveness by analysing destination efficiency', Tourism Economics, Vol 14, No 2, pp 325-342.

Crouch, G.I. (2011), 'Destination competitiveness: an analysis of determinants attributes', Journal of Travel Research, Vol 50, No 1, pp 27-45.

Crouch, G.I., and Ritchie, J.R. (1999), 'Tourism, competitiveness, and societal prosperity', Journal of Business Research, Vol 44, pp 137-152.

Dwyer, L., and Kim, C. (2003), 'Destination competitiveness: determinants and indicators', Current Issues in Tourism, Vol 6, No 5, pp 369-414.

Enright, M.J., and Newton, J. (2005), 'Determinants of tourism destination competitiveness in Asia Pacific: comprehensiveness and universality', Journal of Travel Research, Vol 43, pp 339-350.

Exceltur (2010), Monitur 2009. Monitor de Competitividad Turística de las Comunidades Autónomas Españolas, Madrid.

Gomezelj, D.O., and Mihaliè, T. (2008), 'Destination competitiveness-applying different models, the case of Slovenia', Tourism Management, Vol 29, No 2, pp 294-307.

Gooroochurn, N., and Sugiyarto, G. (2005), 'Competitiveness indicators in the travel and tourism industry', Tourism Economics, Vol 11, No 1, pp 25-43.

Hjalager, A.M. (2000), 'Tourism destinations and the concept of industrial district', Tourism and Hospitality Research, Vol 3, pp 199-213.

Hudson, S., Ritchie, B., and Timur, S. (2004), 'Measuring destination competitiveness: an empirical study of Canadian ski resorts', Tourism and Hospitality Planning and Development, Vol 1, No 1, pp 79-94.

ISTAT (1996), Rapporto Annuale. La Situazione del Paese nel 1995, Istituto Poligrafico e Zecca dello Stato, Rome.

ISTAT (1997), I Sistema Local del Lavoro 1991, Istituto Poligrafico e Zecca dello Stato, Rome.

Kalnins, A., and Chung, W. (2004), 'Resource-seeking agglomeration: a study of market entry in the lodging industry', Strategic Management Journal, Vol 25, No 7, pp 689-699.

Kozak, M., and Rimmington, M. (1999), 'Measuring tourist destination competitiveness: conceptual considerations and empirical findings', Hospitality Management, Vol 18, pp 273-283.

Lazzereti, L., and Capone, F. (2008), 'Mapping and analysing local tourism systems in Italy, 19912001', Tourism Geographies, Vol 10, No 2, pp 214-232.

Marshall, A. (1890), Principles of Economic, MacMillan, London.

Mazanec, J.A., and Ring, A. (2011), 'Tourism destination competitiveness: second thoughts on the world economic forum reports', Tourism Economics, Vol 17, No 4, pp 725-751.

Mazanec, J.A., Wöber, K., and Zins, A.H. (2007), 'Tourism destination competitiveness: from definition to explanation?', Journal of Travel Research, Vol 46, pp 86-95.

Miller, M.M., Henthorne, T.L., and George, B.P. (2008), 'The competitiveness of the Cuban tourism 
industry in the twenty-first century: a strategic re-evaluation', Journal of Travel Research, Vol 46, pp 268-278.

Miret, L., Segarra, M.V., and Hervás, J.L. (2009), 'Un análisis sobre la Concentración Espacial en el Turismo Valenciano', paper presented at the XXXV Reunión de Estudios Regionales, Valencia, Spain, 26-27 November.

Pereira, J., Claver, E., and Molina, J.F. (2011), 'Efectos empresa, grupo estratégico y localización en el sector hotelero español', Cuadernos de Economía y Dirección de la Empresa, Vol 14, No 2, pp 123138.

Perles, J.F., Ramón, A., and Sevilla, M. (2011), 'Determinants of the competitive advantage of residential tourism destinations in Spain', Tourism Economics, Vol 17, No 2, pp 373-403.

Porter, M.E. (1990), The Competitive Advantage of Nations, The Free Press, New York.

Rumelt, R. (1991), 'How much does industry matter?', Strategic Management Journal, Vol 12, No 3, pp 167-185.

Sengenberger, W., and Pyke, F. (1991), 'Small firm industrial districts and local economic regeneration: research and policy issues', Labour and Society, Vol 16, No 1, pp 1-25.

Short, J.C., Ketchen, D.J., Palmer, T.B., and Hult, T.M. (2007), 'Firm, strategic group, and industry influences on performance', Strategic Management Journal, Vol 28, No 2, pp 147-167.

Ybarra, J.A. (1991), 'Determinación cuantitativa de distritos industriales: la experiencia del país Valenciano', Estudios Territoriales, Vol 37, pp 53-67. 